\title{
Analysis of Types of Ecolexicon Expression in Conservation News Texts in Mass Media: Ecolinguistics Perspective
}

\author{
Tommi Yuniawan \\ Languages and Arts Faculty \\ Universitas Negeri Semarang \\ Semarang, Indonesia \\ tommiyuniawan@mail.unnes.ac.id \\ Rustono \\ Languages and Arts Faculty \\ Universitas Negeri Semarang \\ Semarang, Indonesia \\ rus_tono58@yahoo.co.id
}

\author{
Fathur Rokhman \\ Languages and Arts Faculty \\ Universitas Negeri Semarang \\ Semarang, Indonesia \\ fathurrokhman@mail.unnes.ac.id \\ Hari Bakti Mardikantoro \\ Languages and Arts Faculty \\ Universitas Negeri Semarang \\ Semarang, Indonesia \\ haribaktim@mail.unnes.ac.id
}

\begin{abstract}
The objective of this research was to analyse the types of ecolexicon expression in conservation news texts in mass media. The conservation news texts contained language expressions of events or conservation written in accordance with the idea of the vision of conservation-based university (UNNES). There were language expressions in the conservation texts related to the environment and the ideology. Theoretically, reciprocal relationship between environment and language was studied in ecolinguistics. Within the scope of ecolinguistics, the relationship between language and environment laid at the level of lexicon. The data of this research was fragments of conservation news texts presumed as ecolexicon from the mass media: page www.unnes.ac.id, Suara Merdeka, and Kompas since March 2010 until March 2017. The data collection techniques were scrutinizing, documentation, and interview. The data analysis used distributional method and identity method of ecolinguistics and interactive analysis. Based on the data analysis, the types of ecolexicon in conservation news texts in mass media were: (1) metaphor, (2) personification (3) euphemism, (4) dysphism, (5) synecdoche, (6) hyperbole, (7) metonymy, (8) association, (9) pleonasm, (10) antithesis. Therefore, the recommendations were: (1) conservation ecolexicon needed to be used in the mass media texts in order to give knowledge and comprehension to the society concerning environmental condition and (2) the types of ecolexicon expression in the conservation news texts could be utilized as teaching materials by teacher or lecturer in language learning or other learning at school or in college to enrich the text genre and foster the value of love to the environment.
\end{abstract}

Keywords-conservation news texts; ecolinguistics; types of ecolexicon expression

\section{INTRODUCTION}

Conservation news texts in mass media are lingual phenomena. Conservation news texts contain ideas or thoughts on events of conservation-based university written in accordance with the argumentation concerning the vision of the mass media. Conservation is one of the most important topics to the society. Then, conservation news texts in mass media cling to the relationship between language and environment.

In Halliday's view, text is interpreted dynamically. Text is a language that is performing a specific task in the context of situation (Halliday \& Hasan 1992, p. 13). The text relates to what is actually done, interpreted, and said by the society in a real situation. Fill and Muhlhausler (2001, p. 3) state that there are four things that enable the relationship between language and environment, (1) language is free and full of meaning; (2) language is created by the world; (3) the world is created by language (the structuralist and post-structuralist view); and (4) language interconnects with the world (both of which compile each other and are arranged but sometimes independent). The mutual change between environment and language is learned through ecolinguistics studies.

Ecolinguistics examines ecosystem as a part of the human life system (ecology) with the language humans use to communicate in their environment (linguistics). According to Lindo and Bundsgaard (2000), there is a dialectical ecolinguistics theory. This dialectical ecolinguistics theory holds that the forms of ecolexicon and ecodiscourse are classified into words, compounds of words, even sentences in three relational dimensions. Sapir (in Fill and Muhlhausler 2001: 2) states that within the scope of ecolinguistics, the relationship between language and environment is at the level of lexicon, not, for example, at the phonological or morphological level. Mbete (2009, p. 11) argues that a set of words that describes the condition of biotic (flora and fauna) and abiotic (rock, clay, water) environment of a language area lives and is used is called ecolexicon.

Alexander and Stibbe (2011, p. 7) defines ecolinguistics as a study of the impact of language use in survival that bridges the relationship among humans, other organisms, and the 
physical environment that is normatively oriented towards the preservation of sustainable relationships and life. Mbete (2013, p. 17) asserts that language changes and dynamics, including lexicon, represent a change in the physical environment. Therefore, the study of the types of ecolexicon expression in conservation news texts in the mass media becomes an opportunity to review language interdisciplinarily and on the other hand, it enhances the understanding that news is a complex structure of language, thought, action, and social construction.

Furthermore, Haugen (in Fill and Muhlhauster 2001, p. 4) describes that there is a relationship between metaphor and ecolinguistics. Haugen described that there is interaction between language and particular environment. Ecolinguistics does not only talks about the language of biology but also more than how humans interpret the language of biology or natural language, and how the role of language in an environment or social ecology.

Schultz (in Fill and Muhlhauster 2001, pp. 109-110) states that there are three tools of linguistics or language often used in texts related to the commercialization of the environment, namely (1) the use of neutral words that have the connotation of praise or tend to favor the exploitation, but the reality represented by the words is very different. For example, the use of words or terms ecologically sustainable development, fertilizer and human resources; (2) frequently used tools i.e. the use of euphemism (mentioning objects or something unpleasant to be more polite). For example, the use of terms clearing, harvest, greenhouse effect and global warming; and (3) rarely used but very powerful tools when they are used i.e. the use of pejorative or dysphemism (mentioning signs or something with a more negative connotation). For example, the use of words or terms earthworm food and animal's homes to mention humus.

Then, Trampe (in Fill and Muhlhausler 2001, pp. 238-239) states that the environmental texts (greenspeak or greengramatical) with all their manifestations in the mass media contain the following: (1) reification which is to treat living things as economic value objects, related to technology and ideology; (2) hiding the fact i.e. the use of euphemism to replace some words or terms that are avoided; (3) expressing hatred or resistance to parties damaging traditional or customary land; and (4) creating slogan and element that convey ideas and thoughts to make environmental and cultural destruction undertaken by a group of people as if they are appropriate and in accordance with the law of nature.

Relating to metaphor, ecolinguistics requires an understanding or a perspective or an expressive description of meaning. An expressive statement of meaning is very difficult to avoid the associated characteristics in the subject (Taylor 2002, p. 130). Furthermore, Taylor (2002) asserts that expression is the power of the subject; the expression manifests the thing because it basically refers to the subject, to whom these things manifest. What is manifested by expression can only be explained apart from the expression. Then, Wijana (2010, p. 69) affirms that the words, phrases, and pieces of speech used to refer to the reality that exist outside of the language is a language expression.

Keulartz (2007) in a research article entitled "Using Metaphors in Restoring Nature" states that there are four types of metaphors commonly used in shaping ecological restorations: metaphors in the field of machinery and cybernetics; art and aesthetics; medicines and health care; and geography. This metaphorical utilization is for certain purposes, honors and contexts. Keulartz's research (2007) has similarities with this research which commonly examine the matters of language in the news about nature conservation. The difference lies in the research focus being analyzed. Keulartz's research (2007) focuses on the use of metaphor related to environment and nature conservation. This research focuses on the analysis of the types of expression in the conservation news texts in the mass media.

Then, the research on the linkage of environmental reporting to mass media by Laili (2012) entitled "Euphemism and Dysphemism on Environmental Discourse: a Critical Ecolinguistics Study in Mass Media in Indonesia". The research examines language problems contained in the environmental discourse in the mass media in Indonesia which is about euphemism and dysphemism. The research finds the form, reference, types of expression as well as the function of expression unit of euphemism and dysphemism on environmental discourse in mass media in Indonesia. Laili's research (2012) has similarities with this research in terms of the use of ecolinguistics studies with problem limitation only to the expression of euphemism and dysphemism on environmental discourse in mass media in Indonesia, whereas this research focuses on the analysis of form and meaning, types of expression, function, as well as the level of ecolexicon literacy in conservation news texts in mass media to the academic community and alumni of UNNES. The data used in Laili's research (2012) is written data about environmental discourse from mass media while this research takes written data in the form of ecolexicon in conservation texts in mass media.

Theoretically, this research is beneficial to (1) increase the treasury of ecolinguistics studies especially about the types of ecolexicon expression in conservation news texts in mass media, (2) enrich analysis model of the types of ecolexicon expression in the conservation news texts in mass media, and (3) present an ecolinguistic study that combines ideological, sociological, and biological dimensions which is a relatively recent study. Practically, the results of this study contribute to educational institutions to (1) become the basic substance of Indonesian language learning and foreign or local conservation ecolexicon-based learning for students at the primary and secondary school level as well as university students, (2) provide teaching materials for teachers or lecturers in the form of news texts especially conservation news texts --- green text on conservation --- which is one of the types of texts in the basic competencies of the curriculum 2013; and (3) add information about news texts especially conservation news texts for readers.

\section{METHOD}

This research focused on the types of ecolexicon expression in conservation news texts in mass media. The data of this research was fragments of conservation news texts presumed as ecolexicon. The data sources of this research were conservation news texts in mass media from the page of www.unnes.ac.id, Suara Merdeka, and Kompas since March 
2010 until March 2017. The data collection techniques were scrutinizing, documentation, and interview (Sudaryanto 2015, p. 133; Mahsun 2005, p. 133; Kesuma 2007, p. 43; Mbete 2013 , p. 34). In this research, the instrument or research tool used is human instrument or the researchers themselves. This is in accordance with Moleong's statement $(2007$, p. 8) that in qualitative research, the main key instrument is the researcher so the researcher should be "validated". Furthermore, the data analysis used distributional method and identity method of ecolinguistics and interactive analysis.

\section{RESULT AND DISCUSSION}

\section{A. Types of Expression in Conservation News Texts}

The data analysis of the types of expression is classified into three main pillars of UNNES conservation, namely (a) the pillar of value and character, (b) the pillar of art and culture, and (c) the pillar of natural resource and environment. Based on the analysis of news discourse in www.unnes.ac.id, Harian Suara Merdeka, and Harian Kompas, it is obtained the data of ecolexicon types as follows.

\section{1) Metaphor}

Metaphor is the use of words or group of words not with the actual meaning but as an illustration based on similarity or comparison. Metaphor is a language style formed on the basis of comparison or similarity to find traits that show the similarity between two things (Keraf 2004, p. 139). In conservation-oriented texts, the pillar of value and character are found in the type of metaphor ecolexicon expression to describe a situation as an explanation in the text. Here are some quotes of metaphorical data in conservation-oriented news texts.

a) Including UNNES, none of the universities in Central Java listed in the "top 95". Nonetheless, throughout Indonesia, UNNES is under the "bayang-bayang" of University of Indonesia, Sepuluh November Institute of Technology of Surabaya, Bandung Institute of Technology, and University of Bengkulu. (04/WB/17 December 2010).

b) On the other hand Ki Teguh said that impasse would occur if the courses had no intervention from many parties. "Aja nganti kegedhen empyak kurang cagak - never let great willingness not supported by inadequate things," he explained. (64/WB/29 December 2012)

From the data (1), derived word bayang-bayang is used to explain the position of UNNES ranking in Green Matric. It is not enough with just the description "under the University of Indonesia", the sentence is still equipped with a metaphor of shadow. According to its meaning, bayang-bayang is a space that is not subject to light due to shielded an object or a black form behind the object in the rays. The use of the metaphor bayang-bayang represents the position of Semarang State University in the second rank in Green Matric is still covered by the black form of the object exposed to light, ie UI. In this context, the light is interpreted as a victory or first rank obtained by UI.

In the next data, the metaphor is manifested through the use of the Javanese term that has a certain meaning. In the data (2), the authors use the term in Javanese language that can be categorized as a metaphor, ie the proverb aja nganti kegedhen empyak kurang cagak. Literally, the proverb aja nganti kegedhen empyak kurang cagak in Indonesian language means the roof of the house is too large while the pillar of the house is still lacking. The proverb is used to convey a big dream which is not supported with sufficient ability in terms of knowledge, health, capital and so on. In Indonesian, the proverb is similar to besar pasak daripada tiang (the peg is larger than the pole).

In the conservation-based texts of the pillar of art and culture found three data using metaphorical language style in the delivery of information. The three data are as follows.

c) We are certainly familiar with the classical Javanese expression ajining gumantung saka busana that literally means the value of the body is determined by the clothe worn. The phrase is now felt to find its actuality again in the Exhibition of Conservation Technology of Services and Production (TJP) Class of 2009, at the auditorium of UNNES Sekaran, Tuesday (26/6). (47/WB/26 June 2012)

d) Previously, the Rector of UNNES conveyed that Sinden Idol was held as an effort to preserve one of the cultural icons of the Archipelago. "Do not let us just kebakaran jenggot after another nation claims sinden as their own," he said. (59/ WB/29 October 2012).

e) Sucipto said that art tradition was having seclusion in the midst of modern society that should breed it. "For example, wayang krucil, opak obong, and jathilan which are hidup segan mati tak mau, the television media does not give place especially in the hours that have many viewers," said the lecturer of Department of Javanese Language and Literature FBS UNNES. (61/WB/14 October 2012)

From the data (4), the authors use the term or phrase in the Javanese language, namely ajining raga gumantung saka busana. Proverb is used to describe the activities of Exhibition of Conservation Technology of Services and Production (TJP) Class of 2009 at the auditorium of Semarang State University. In the Indonesian language, the phrase is interpreted that the worth of someone's appearance can be seen from the clothes they wear. Furthermore, in the data (5) the authors use the phrase kebakaran jenggot. The phrase classified as metaphorical language style means confusing situation. The use of the term kebakaran jenggot in the sentence is used to represent the attitude of Indonesia if other nations claim sinden or other Indonesian cultures as their cultures. Besides being in line with the context of the sentence, the use of the metaphorical language style kebakaran jenggot leaves a more strong impression and becomes a kind of reminder to its 
readers. With the word kebakaran which literally means burning something and make a person suffer, the reader will be more impressed and then become an implied mandate submitted by the authors.

Furthermore, in the data (6), the authors use proverb hidup segan mati tak mau which means miserable life, either because of illness, misery, or because of economic condition that is far from sufficiency. The proverb is used by the speaker to represent Javanese culture in the speech especially the arts, in the current conditions amid the onslaught of foreign cultures. The proverb is also used to show the impact of the uninterested television to provide slot for local arts shows in prospective hours. The authors deliberately add the quotation in the news to show the condition of Javanese art that is in a critical period through the proverbial hidup segan mati tak mau.

Metaphor focuses on comparisons of things that are commonly understood over a certain similarity. In the conservation news texts of the pillar of natural and environmental resources, there are nine metaphorical language usage as follows.

f) Indeed, the planting movement proclaimed by the rector of UNNES since several years ago has now resulted. In all corners of the 125-hectare campus, it looks ijo royo-royo. (03/WB/27 December 2010)

Based on data above, the authors use the same language style namely ijo royo-royo to describe an area as the target of conservation of State University of Semarang. The term ijo royo-royo derives from Javanese language which means to grow and flourish with fresh green leaves full of shade so that it brings benefits to all living things. Metaphoric language style is used to describe the environment of Semarang State University as well as represent the hope of Semarang State University to create a place that can be useful for others because of the trees.

In addition to the word ijo royo-royo, the use of Javanese language in the strategy of metaphoric language style is also found in the following data.

g) While the Rector Prof Sudijono Sastroatmodjo said that Suara Merdeka and UNNES had already been like relatives. "Mr. Budi Santoso (Commissioner of SM-Red) is one of the boards of the university, so if Mr. Kukrit now takes care UNNES too, that means nunggak semi pada rama," he said. (03/WB/27 December 2010)

h) Former Minister of Environment Rachmat Witoelar today (Friday, 22/3) visited UNNES Sekaran campus. Besides discussing the environment with lecturers and students, Rachmat also "tilik tanduran". Yes, he checked the tree he planted in 2008. Five years ago this man had participated to green Sekaran campus. (73/WB/22 March 2013)

From the data (7), there are words semi nunggak pada ramanya representing the sprout plant of a stump or the remaining part of an old plant. It is a process of change that produces innovation but grows from the old remnants that have been decayed. The word nunggak semi was chosen to represent what Cukrit did is similar to the process of regrowing from the routine that had been done by Budi Santosa as the board of Semarang State University. Other than nunggak semi, the words tilik tanduran are contained in the data (8). The verb of tilik tanduran in Indonesian means to visit plants that have been planted before. In that data, tilik tanduran is not only interpreted literally but also a metaphor of re-visiting and seeing the results of a process.

In addition to using Javanese language as a means of metaphor, there are also found some data of strategy of metaphorical language style in Indonesian language. The data is as follows.

i) Acting Chief of PON XVIII Syamsurizal said that konsep hijau became the demand of the world. "This is not a local issue, but the demand of the world. (05/WB/14 January 2011)

j) "The event is conducted in the form of Environment Development, Community Development and Unit Development. As many as 130 scouts are going to menghijaukan Merapi by involving 22 instructors from UNNES, teachers and elementray students from Kecamatan Dukun and local communities," said Syaifur Rizqi Zein Chairman of Sangga Kerja Kemah Bakti Merapi (25/WB/2 June 2011)

k) Engineering Faculty (FT) of Semarang State University (UNNES) commemorated the earth day by doing reforestation in the surrounding area of Jatibarang Reservoir, Wednesday (22/4). The activity is one of the concrete actions of conservation sabuk hijau at the ledges of Jatibarang Reservoir. (103 / WB / April 22, 2015)

The data (9) to (11) have similarities in the use of words i.e. using the word hijau as one element. The word hijau in metaphor means relating to movement, spirit, issues, etc. aimed at reducing the greenhouse effect and global warming. In a sense, the word green is correlated with conservation movement. The metaphor is then pinned on several terms, they are konsep hijau, menghijaukan merapi, and sabuk hijau. The meaning of sabuk hijau is a green open space which the main objective is to limit the development of a land use or restrict one activity to others so they do not bother each other. In addition to the use of the word hijau, in the pillar news texts of natural resources and environment also found the term diet plastic as the following text.

1) "Students are also introduced about the utilization of used goods, that is conservation glass and bags from used banners as a form of diet plastik to reduce the use and production of plastics," he explained. (75 / WB / 22 April 2013) 
The term diet plastik in the data (12) is a metaphor which means to reduce the use of plastics in daily activities by recycling and so on. The term diet plastik is also known as diet katong plastik which is diet plastik devoted to the reduction of plastic bags usage when shopping. The metaphor strategy is used to represent the reduction of plastic bags for health and a better life since the word diet is generally related to body and weight to stay healthy.

\section{2) Personification}

Personification is a language expression that compares inanimate or immovable objects so that it seems living and be able to behave like a human. Personification is a kind of figurative speech that depicts inanimate objects or lifeless things as if to behave like humans (Keraf 2004: 142). In line with the definition, personification also means a language style that attaches human attributes to inanimate objects or to abstract ideas. Personification is often used to express the attitude or action of objects that seem to be capable of performing activities and things like human beings. Here are the data found in the pillar of value and character.

a) Alun tetabuhan mengusik sepi. That night, like the previous nights, the cold burst. Mangsa ketiga presents an unusual breeze. (53/WB/8July 2012)

b) Building on the right and left is intended to menampung produk karya seni lukis dan kriya yang selama ini belum memiliki 'rumah'. In that place, art exhibition can be held with a qualified facility. (99/WB/6 January 2015)

Personification in the data (13) is in the first sentence alun tetabuhan mengusik sepi. The word mengusik means to annoy, tease, touch, or offend. In general, which can mengusik is human but in that sentence the word mengusik is pinned on alun tetabuhan and sepi. Such strategy is used to build the atmosphere in the news text more alive and to give a deep meaning.

Meanwhile in data (14), personification is found in the quotation menampung produk karya seni lukis dan kriya yang selama ini belum memiliki 'rumah'. Rumah is a building for human to live but in that phrase the artwork and craft products are personified to be homeless people. It represents that the readers and relevant parties are expected to pay more attention to the products of artwork and craft like human who needs a place to live.

In the conservation news texts of the pillar of natural resources and environment are personifications to provide a clearer description and illustration. The use of language style strategy of personification is as follows.

c) "During the journey we spread conservation virus at colleges and we were welcomed even the ones we visited stated that they ingin mengadopsi konsep konservasi. Among others, at Surabaya State University (Unesa) was welcomed by the Vice Rector for Student Affairs (PR III), at Udayana University was welcomed by the Vice Rector III and Balinese bike community, at Mataram University was welcomed by the rector who wanted to cooperate with UNNES, " said the alumnus of Biology. (28/WB/2 July 2011).

d) "Once I was unable to attend the community service, pohon-pohon yang dianggap mengganggu jalan 'dihabisi'. It made the atmosphere so arid. I was crying, to whom I must complain," he said. Chairman of the committee Warsono said that proactively he had asked for donation to anyone untuk ikut menjadi 'pengasuh' pohon langka. "One rare tree is charged IDR 250 thousand per year for the care. We will hand over the management directly to the head of RT where the tree grows, "he told several members of the Regional Representative Council (DPD) of Central Java (52/WB/14 June 2012)

The data above has a similarity in the use of word choice. In the data (15), there is word adopsi. The word adopsi means the adoption of other people's child as their own. In general, the word adopsi is used to express a person's custody. Therefore, the data (15) is classified as a personification language style. Similar words exist in the data (16) i.e. the use of word dihabisi and pengasuh. The word pengasuh refers to someone in charge of raising a child or someone else. However, in the data, pengasuh is in charge of keeping and maintaining the tree. The use of personification in the data represents that the environment and trees including one of its elements must be kept and maintained as human beings. Other data from the use of personification is as follows.

e) Indeed, after Bank Mandiri provided 700 bikes, there are now almost seribu sepeda bersemayam di universitas konservasi. (07/WB/5 January 2011)

The word bersemayam means staying or saved which is generally used to describe a person's situation and condition. However, in that data, the word bersemayam is used to describe the position of sepeda (bicycle). The use of personification strategy in the data is intended to make the sentence more alive. In addition to the data, here are other data found using personification.

f) Besides the weaknesses that must be acknowledged, according to Prof. Dodi, UNNES also has great power. One of them has a long history, strong togetherness, and solid leadership-membership. "UNNES juga mesti wangi, harus banyak menanam kebajikan, dan harus paham tantangan," said the former Secretary General of Ministry of National Education. (31/WB/26 October 2011)

g) In addition, it is also expected dapat menjadi juru damai antara bumi dan sampah. So that created a beautiful day for earth and garbage. (43/WB/23 April 2012) 
h) Bila Pohon Langka Saling Sapa. (52/WB/14 June 2012)

i) Entering the area of Semarang State University in Sekaran, Gunungpati, Semarang, Central Java, kesejukan menyergap. Rimbun pepohonan menyambut. The security guards stand at the gate and direct motorcycles or cars to park before entering the campus area (128/KP/4 March 2014)

From that data, personification is used as a strategy to describe a situation and represents that conservation and all the elements in it are very closely related to humans so that it can be considered to have the nature and should be positioned as human being. The four data put Semarang State University and plants as subjects that are considered as human being that are capable of performing action (verb).

\section{3) Euphemism}

Euphemism is the use of a term to replace inappropriate expressions to avoid embarrassment both the person being spoken to and listening (Allan and Burridge 1991, p. 11). Inappropriate expressions can be taboo words, something frightening or some reasons that have negative connotations for speakers and others who hear. In the conservation news texts of pillar of value and character, it is found a data using euphemism style as follows.

a) One of the participants of planting program, Natalia Hersaniati with keterbatasan fisiknya showed the courage towards the garden to plant durian tree seed. He hoped that the planted trees could grow and be fruitful to the local scoiety. (112/WB/11December 2015)

Based on the data (22), the authors use the phrase keterbatasan fisiknya to avoid mentioning disability of the body. It is used to appreciate Natalia Hersaniati and refine the word for the sake of maintaining ethical politeness. Accordingly, now the government and all related agencies are no longer use the word defective instead of disable to explain the condition of a person. In addition, euphemism language style is also found in the following data.

b) "When my vehicle entered UNNES, I was really amazed at the green environment. Bahkan saya minta sopir agar memelankan laju kendaraan. Saya takut asap knalpot kendaraan kami membuat polusi di lingkungan yang cantik dan hijau ini," he said as a seminar speaker at UNNES on Thursday (9/6). (26/WB/9 June 2011)

The data (23) contains language style that represents a person's feeling and thought. It is clear that Syamsul Maarif as the Head of Disaster Management Agency pays so much attention to environmental condition around Semarang State University. The expressed phrase has refinement function for the fear of actions that will damage the well-ordered and wellconditioned environment. In the data (23), there is Bahkan saya minta sopir agar memelankan laju kendaraan. Saya takut asap knalpot kendaraan kami membuat polusi di lingkungan yang cantik dan hijau ini. The quotation implies a refinement of euphemism about the natural conditions that must be maintained. Webster (1997, p. 222) states that euphemism is a smoother expression to replace irreverent expressions. Inappropriate expressions can be taboo words, something frightening, or some reasons that have negative connotation for the speakers and others who hear.

\section{4) Dysphemism}

Dysphemism is an expression with painful connotations to the speaker and the listener so the expression is usually replaced by the more neutral or more euphemistic ones (Allan and Burridge 1991, p. 26). Dysphemism is used to talk about opponent, something that is expected to show displeasure, as well as something that is expected to be more insulting, disparaging or demeaning to the opponent. Meanwhile, Keraf (2004, p. 132) argues that dysphemism is a language style contrary to euphemism.

a) Some of the bikes are already used, but the others are masih relatif nganggur. (07/ WB/5 January 2011)

The data (24) shows a language style to coarsen the words with a particular purpose. In the quotation (24), there is masih relatif nganggur. In the quote, a rough portrayal of reference to bicycles at Semarang State University is shown. The word nganggur is considered quite harsh, because it gives an affiliated lexical meaning to the unbeneficial. In addition, the use of the word will create a negative impression because it seems not useful. Allan and Burridge (1991, p. 31) says that dysphism is a word or phrase that connotes painful or disturbing to the person whom being spoken to, and the person whom being talked as well as the person who hears the phrase.

\section{5) Synecdoche Totum Pro Parte}

Synecdoche is a language style that mentions a part of something as a substitute for the name of the goods. According Keraf (2004, p. 126), synecdoche is a figurative language that uses part of the things to express the whole (pars pro toto) or use the whole to express a part (totum pro parte). Synecdoche is divided into two, namely synecdoche pars pro toto and synecdoche totum pro parte. Synecdoche pars pro toto is used to mention part of object, place, or concept that represents the whole thing. Synecdoche totum pro parte is the opposite of pars pro toto to mention the whole of object, place, or concept representing part of it. Here is the data that shows the use of language style of synecdoche totum pro parte.

\section{a) Universitas Negeri Semarang (UNNES) sedang mengembangkan a model of conservation-based character education for university. Now tim pengembang is collecting data and compiling the academic script (02/WB/10November 2010)}

Based on the data (25), the authors use Universitas Negeri Semarang (UNNES) to represent the word tim pengembang. This is in accordance with the principle of the language style 
of synecdoche totum pro parte i.e. mentioning the whole object, place, or concept that represents part of something. Basically the ones who develop conservation-based character education model is tim pengembang (development team) as described in the second sentence but at the beginning of the sentence the authors prefer using Semarang State University. It is used as a branding strategy to highlight the institution, Semarang State University. Other data in the style of synecdoche is as follows.

b) Whatever the dream, the main goal of Universitas Negeri Semarang (UNNES) is to improve the quality of sustainable productivity. Thus, this conservation university needs to recognize its identity, including its weaknesses and strengths. (31/WB/26 October 2011)

From the data (26), there is a language style that mentions the whole of something to represent its part. In the quotation (35), there is Universitas Negeri Semarang (UNNES). The quotation shows the larger part accommodates the smaller parts. The examples of the smaller parts are academic community, institutional, facilities until all the functions within the university. It is represented in the quote that mentions UNNES.

\section{6) Hyperbole}

Hyperbole is a language style that contains an exaggerated statement by exaggerating something (Keraf 2004, p. 141). In a broader sense, hyperbole is a language style that exaggerates what really means to intensify, enhance the impression and influence, either the number, size, or properties. The use of hyperbolic language styles was also found in conservationbased news texts. Here is data from the quotes.

a) Who does not know Rara Jonggrang? The girl who is always described as a perfect figure is believed to be the forerunner to the building of Prambanan Temples. Due to her request, Bandung Bondowoso berusaha membangun seribu candi dalam semalam. When Bondowoso was captivated by Jonggrang's beauty, he immediately declared himself to marry her. But Jonggrang did not want to. She did not want to marry the man who had killed his father. She then gave impossible request. Bondowoso diminta membangun seribu candi dalam waktu semalam. Bondowoso accepted the request. Dengan mengerahkan bala bantuan makhluk halus, the son of the Pengging Kingdom ruler almost succeeded. In fact he was sure to finish all of them, before Jonggrang finally deceived. She deceived the spirits who helped by sounding mortars, the sign that the day had been morning. The temples were failed to build with the number of a thousand temples. Bondowoso was furious. Kemudian kita tahu, Jonggrang digunakan sebagai pelengkap candi keseribu itu. Ia terfosilkan menjadi kisah abadi yang hingga kini masih saja dapat kita ceritakan kembali. (49/WB/24 June 2012)
The data (27) is a text that tells about a drama performance by college students. One of the dramas played is about the origin of Prambanan Temples. The drama is classified as a legend story. Like the most of the legend stories, there is hyperbolic language style or exaggerated condition when correlated with the current facts. The first hyperbolic language style strategy found is in sentence Bandung Bondowoso berusaha membangun seribu candi dalam semalam. When correlated in literal meaning and condition of a normal human, it is not possible to build a thousand temples overnight.

The hyperbole strategy is continued in the sentence dengan mengerahkan bala bantuan makhluk halus danKemudian kita tahu, Jonggrang digunakan sebagai pelengkap candi keseribu itu. Ia terfosilkan menjadi kisah abadi yang hingga kini masih saja dapat kita ceritakan kembali. Movering the spirits to build the temples is one of the hyperbolic language style contained in the legend of Prambanan Temple. In the human world, it is not possible that spirits are capable to build temples. Finally, it is said that Jonggrang was condemned to be the thousandth temple and completed the total temples made by Bandung Bondowoso. In everyday life, it is an exaggeration when someone is said to be capable of transforming a person into a fossil or a temple stone. However, since the hyperbolic style strategy is used for a legend story, it becomes reasonable and just as a story without believing the truth.

Besides the news text quote of Prambanan Temples, the use of hyperbolic language styles is also found in the following data.

b) A choreography entitled "Tongcling" opened Dance Show 2012 organized by the students of Dance Education of Sendratasik (Drama Dance and Music Arts) of Languages and Arts Faculty (FBS) UNNES, Saturday (16/6). The annual event held at B6 was mampu membius ratusan penonton. (50/WB/17 June 2012)

The data (28) is a quote from conservation-based news text of the pillar of art and culture informing the dance performance organized by the students of Dance Education of Sendratasik (Drama Dance and Music Arts), Languages and Arts Faculty, Semarang State University. In this event, various choreography and composition of the students are performed. The author uses hyperbolic language style mampu membius ratusan penonton in the news texts to create an impressive impression. The verb 'membius' means to do anesthesia or make unconscious (loss of memory). Anesthesia is usually performed by medical or health personnel using drugs. In other words, anesthetize also means to make lulled. Therefore, the clause mampumembius ratusan penonton can be categorized as hyperbolic language style.

Hyperbolic language style is also found in the data of the pillar of natural resources and environment as follows.

c) As an illustration, in Pemira in the previous year, it takes 35 reams of paper with a price range of IDR 5.5 million. Contrary to the selection this time, kertas tak dibutuhkan sama sekali, except laptop which actually 
has been facilitated by the university. $(06 / \mathrm{WB} / 6$ January 2011)

From the data (29), there is a hyperbolic expression associated with the implementation of Pemira. UNNES has implemented Pemira online by using laptop as the primary means. In the sentence kertas tak dibutuhkan sama sekali is categorized as hyperbole expression because it is an exaggerated statement. Although it has been implemented online, mail administration and so on are still using paper to print.

\section{7) Metonymy}

Metonymy is a language expression used to mention an object or other things by using a brand. Metonymy is a language style that uses a word to express something else because it has a very close relationship. The relationship can be; effect to cause, cause to effect, content to declare the surface, and so on (Keraf 2004, p. 126). Generally, the use of metonymy is caused by people that have known so well about the brand and understood the meaning when only mention the brand. In the data of the pillar of natural resources and environment, there are quotations using metonymy. The data are as follows.

a) Margunani, MP the team leader during the visit of the Rector of UNNES on Sunday (27/3), in Boyolali said that she handed over tool aids such as a garbage chopper machine, three sets of corn sheller, three sets of cornmeal tool and 20 sets of Takakura compost maker. "In addition, three sets of organic and inorganic waste sorting bin, cooking utensils for making cakes from corn (stoves, blenders, mixers, oven, and others each three sets," said Margunani. (12/WB/30 March 2011)

b) "Currently, there only five Tossa can be submitted to some faculty, for faculty which have not received, wait patiently in the following year," said the Rector of UNNES. (33/WB/30 December 2011)

Based on the data (30) and (31), there is a language style which links between one thing to another. The language style uses one or two words which is a brand, a kind or others that is a unity of a word. The quotation (30) contains kompos Takakura which refers to a composting method developed by a particular scientist, whereas in the quotation (31), there is a word tossa which refers to the use of a vehicle brand having special function and expression type. In this case, the vehicle is a motorbike with an outboard tub that functions as a threewheeled transport vehicle with the brand tossa.

\section{8) Association}

Association is an expression of a parable language that belongs to a comparative language style. According Keraf (2004, p. 123), parable is an explicit comparison. Explicit comparison means that it does not directly state something the same as anything else. The typical comparison of words to express idea or thought is also found in this language style. Thing that distinguishes between associative language style and other comparative language styles is that associative language style compares the purpose or idea or thought by parabling with other words in one sentence. The parables used in associative language style can be either noun or proverb that describes the meaning of the idea the speaker is trying to express. Associative language style often uses comparative linking words such as seperti, ibarat, bagai and so on, although it can also be without conjunction.

Below are data from conservation news text quotations of the pillar of natural resource and environment using the strategy of associative language style.

c) "Today I physically hand over a tree to the President of BEM KM. But at the same time, I also menanam harapan kepada mahasiswa to build UNNES together through positive actions, not just talk," he said. (08/WB/23 February 2011)

d) When delivering the previous report, the Rector of UNNES mentioned, menanam pohon pada hakikatnya menanam harapan. "To the next generation, we dedicate the seeds that will grow up in the future," said the Rector before submitting 200 coconut seeds to Regent Indartarto. (38/WB/8 January 2012)

e) Tree-planting activity is not only an obligation to green the environment but it also can be interpreted as menanam kebaikan dan harapan. Because by maintaining the environment, nature conservation will be maintained. (101/WB/7 February, 2015)

f) "Menanan pohon sama dengan memberi amal jariah untuk menyejahterakan umat. Because, the trees will be able to prevent disasters and the fruits can be eaten. Fish sown in the pond will be useful to the local society and students to be fished. This is a form of rahmatanlil'alamin," he said while giving a speech at the event themed "Sauwong Sauwit". (18/WB/14 April 2011)

Based on the four data above, there is a same strategy of parable language style that is menanam pohon adalah menanam harapan. The statement is similar to the statement expressed by the 6th President of the Republic of Indonesia, Susilo Bambang Yudhoyono, that is "when we plant trees, we are planting prayers, planting hopes and planting all of our work for the sustainability of the next generation." Equating menanam pohon and menanam harapan represents the tree as a symbol of hope by which life is believed to be better. Trees as the main constituent of the world's lungs are in fact not only useful to humans but also all living beings, both animals and maintaining the ecosystem balance. By planting trees, then someone has tried to increase the intake of oxygen and the ecosystem balance that will later be utilized by the next generation. Therefore, the parable language style is used to say that planting trees is planting hopes. In addition to the clause, the strategy of the parable language style also uses the following words. 
g) "During the journey we spread virus-virus konservasi at colleges and we were welcomed even the ones we visited stated that they want to adopt the concept of conservation. Among others, at Surabaya State University (Unesa) was welcomed by the Vice Rector for Student Affairs (PR III), at Udayana University was welcomed by the Vice Rector III and Balinese bike community, at Mataram University was welcomed by the rector who wanted to cooperate with UNNES, " said the alumnus of Biology. (28/WB/2 July 2011)

h) Furthermore, the Minister of Education and Culture hoped that the effort will raise generation in the near future. "What was once thought to be impossible by the previous generation becomes possible by the present generation, for, as long as we sincerely attempt, 'siapa yang menanam akan memetik' will be applicable" he said. (38/WB/8 January 2012)

From the data (36), association is characterized by the use of virus-virus konservasi words. Virus in literal meaning is microorganism that can not be seen using ordinary microscope but electron microscope, the cause and transmitter of disease. In the field of information technology, virus is illegal program that is inserted into a computer system via network or portable device so it spreads and damages the existing program. In the data (55), the word virus is coupled with the word konservasi. The strategy of parable is carried out by taking the nature of the virus which can transmit and disseminate quickly. Thus, the speaker parables Semarang State University is transmitting and disseminating conservation to all communities and universities and hoping to bring changes for better life.

Then, in the data (37) there is a proverb or life principle that is familiar to the people, who planted will pluck. The proverb represents a causal correlation i.e. all the consequences that will occur essentially are the results or caused by human behavior. In that data, the proverb who planted will pluck represents that everything related to conservation and good actions that have been done are believed to bring good to themselves.

\section{9) Pleonasm}

Pleonasm is to affirm the meaning of a sentence by adding excessive word or phrase. Thus, pleonasm as a language style can be interpreted as the excessive use of words (terms) than is necessary in writing or speaking (Kridalaksana 2008: 135). In other words, pleonasm adds description to a sentence but actually the information is not needed. Though discarded, the sentence has a fixed meaning. However, pleonasm language style makes a sentence sound stronger and clearer. The use of pleonasm language style is found in the following data.

i) "In other words, conservation is harga mati yang tak bisa lagi ditawar," said the Rector of Semarang State University Prof. Dr. Sudijono Sastroatmodjo MSi during a two-year reflection of Conservation University Declaration on Tuesday (20/3) night at auditorium of Sekaran campus. (41/WB/22 March 2012)

Ploenasm in the data (38) is found in the clause harga mati yang tak bisa lagi ditawar. The affirmation in the clause is done with the addition of information yang tak bisa lagi ditawar. Whereas it is known that the meaning of harga mati is a fixed price and can not be negotiable or changed again but the information tak bisa lagi ditawar is still mentioned. The strategy of pleonasm language style is used by the speaker to assert and give impressive impression to the interlocutor. In addition, pleonasm language style shows the spirit of unity and determination to promote conservation in all life aspects.

\section{0) Antithesis}

Antithesis is disclosure of conflicting ideas in parallel arrangement of words. Antithesis is a language style containing conflicting ideas using opposite words or groups of words. This style arises from a balanced sentence (Keraf, 2004 , p. 126). Here are the quotations of data using the antithesis language style.

j) Some of the bikes sudah dimanfaatkan, but others are masih relative nganggur. (07/WB/5 January 2011)

k) "Ada kreativitas di balik ketidakbergunaan sampah," said Eva Banowati, the Head of Waste Management Division of Conservation Development Agency of UNNES in Waste Reuse Training, last week. (55/WB/27 September 2012)

Based on the data (39) and (40), there is language style that compares two opposite things. In the quotation (39), sudah dimanfaatkan is compared to masih relative nganggur while in the quotation (40), there is ada kreativitas di balik ketidakbergunaan sampah. Both quotations clearly point out the opposite, as an explanation to quotation one, the beginning of the quotation addresses benefit but at the end of the sentence compared with nganggur which is the opposite of benefit. In addition, the second quotation refers to the creativity of the waste while it is known that waste is useless but in the quotation the language style seems to compare with creativity that is often interpreted as the utilization of all things that are still useful.

\section{B. Conservation News Text as Teaching Materials}

Environmental problems cannot be solved by only repositioning human relationship with the natural environment, but also through reorientation of value, ethic and life norm that are later concluded in collective actions and restructuring social relationships between individuals, individual and group, group and group, and group with larger organization (e.g. country, international agency). At this point, education is required to develop relevant perspectives (Anwari, 2010). First, education must build the notion that ecological damage is a negative impact of human activities fighting over resources. Second, education sees ecological damage as a bad reality that calls for of human sacrifice. These two things are important to be understood by the world 
of education as the interconnectedness between human and the environment.

Based on the theory that there is correlation between education and environmental sustainability, then the use of conservation news texts as a teaching material to be a relevant alternative and prospective. The Curriculum 2013 uses texts as a general learning base. In this case, language learning is expected to be an introduction of various interrelated subjects. This is in line with the efforts to use conservation news texts as teaching materials. Through conservation news texts, students learn not only the different types of texts and other language learning materials but also natural science, social science, even on the updating of technology related to the environment.

Besides being used as teaching materials for language learning, conservation texts can also be used as reading materials to support the School Literacy Movement (GLS) program. To shape people with excellent quality and synergize in the association to make the environment and nature more beautiful, ecoliteracy is important. The main purpose of ecoliteracy lies in the dissolution of self-concept of antiecology to self-greening concept. The meaning of the term "self" in this context is broadended which attaches itself as an organism. Self with complete meaning. The self-green concept comes from what ecologist Joanna Macy calls "greening of the self." In line with the internalization of the "self-greening" concept, it takes real efforts to promote ecoliteracy as a new lifestyle. Therefore, by reading and critiquing conservation news texts, it is expected that the concept of ecoliteracy and the concept of the importance of maintaining the ecosystem will be realized in every student

\section{CONCLUSION}

The types of ecolexicon expression in conservation news texts in mass media were (1) metaphor, (2) personification (3) euphemism, (4) dysphemism, (5) synecdoche totum pro parte, (6) hyperbole, (7) metonymy, (8) association, (9) pleonasm, (10) antithesis. Ecoliteracy or environmental literacy was the ability or high awareness of the society about the importance of the environment with all its contents that must be maintained, guarded, and used wisely. The level of conservation ecolexicon literacy could be an indicator of ecological awareness of the society in keeping and maintaining the earth sustainably. The types of ecolexicon expression in the conservation news texts could be used as teaching materials for language learning. In addition, conservation news texts could also be used as reading materials in the School Literacy Movement (GLS) aimed at creating "self-greening concept" to the students.

\section{Acknowledgement}

The authors would like to gracefully thank Prof. Dr. Aron Meko Mbete from Universitas Udayana; Prof. Dr. H. Achmad Slamet, M.Si; Prof. Dr. Agus Nuryatin, M.Hum. and Prof. Dr. Ida Zulaeha, M.Hum. from Universitas Negeri Semarang who have thoughtfully discussed the eco-linguistic studies.

\section{References}

Allan, Keith and Kate Burridge. (1991). Euphemism and dysphemism: language used as shield and weapon. Oxford: Oxford University Press.

Alexander, Richard dan Arran Stibbe. (2011). From the analysis of ecological discourse to the ecological analysis of discourse. In Language Sciences. Amsterdam: Elsevier.

Baynham, Mike. (1995). Literacy practices: investigating literacy in social contexts. London: Longman.

Fill, Alwin and Peter Mühlhäusler. (2001). The ecolinguistics reader language, ecology, and environment. London: Continuum.

Halliday, M. A. K. dan Ruqaiya Hasan. (1992). Bahasa, konteks dan teks: aspek- aspek bahasa dalam pandangan semiotik sosial (Terjemahan Asruddin Barori Tou, dari judul asli: Language, context, and text: aspect of language in a social semiotic perspective). Yogyakarta: Gadjah Mada University Press.

Keraf, Gorys. (2004). Diksi dan gaya bahasa. Jakarta: Gramedia Pustaka Utama.

Keraf, Sony A. (2014). filsafat lingkungan hidup. alam sebagai sebuah sistem kehidupan. Yogyakarta. Kanisius.

Kesuma, Tri Mastoyo Jati. (2007). Pengantar (metode) penelitian bahasa. Yogyakarta: Caravatibooks.

Keulartz, J., (2007). Using metaphors in restoring nature. Nature \& Culture, 2(1), 27-48.

Kridalaksana, Harimurti. (2008). Kamus linguistik. (edisi ketiga). Jakarta: Gramedia Pustaka Utama.

Laili. Elisa Nurul. (2012). Eufimisme dan disfemisme pada wacana lingkungan: sebuah kajian ekolinguistik kritis (Tesis). Yogyakarta: Fakultas Ilmu Budaya Universitas Gadjah Mada.

Leech. Geoffrey. (1993). Prinsip-prinsip pragmatik. Terjemahan M.D.D Oka. Jakarta: Universitas Indonesia.

Lindø, Anna Vibeke and Jeppe Bundsgaard (eds). (2000). Dialectical ecolinguistics three essays for the symposium 30 years of language and ecology in graz december 2000. Austria: Univerisity of Odense Research Group for Ecology, Language and Ecology.

Mahsun. (2005). Metode penelitian bahasa: tahapan strategi, metode, dan tekniknya. Ed. Revisi. Jakarta: Raja Grafindo Persada.

Mbete, Aron Meko. (2009). Problematika keetnikan dan kebahasaan dalam prespektif ekolinguistik. Medan: Universitas Sumatera Utara.

Mbete, Aron Meko. (2013). Penuntun singkat penulisan proposal penelitian ekolinguistik. Denpasar: Vidia.

Moleong, Lexy J. (2007). Metodologi penelitian kulitatif. Bandung: Remaja Rosdakarya.

Sudaryanto. (2015). Metode dan aneka teknik analisis bahasa: pengantar penelitian wahana kebudayaan secara linguistis. Yogyakarta: Duta Wacana University Press.

Taylor, Charles. (2002). Bahasa dan hakikat manusia. In Gibbons, Michael T. (Ed) Tafsir Politik. Yogyakarta: Qalam.

Webster, Merriam. (1997). The merriam webster dictionary. USA: Merriam Webster Inc. 
Wijana, I Dewa Putu. (2010). Pengantar semantik bahasa Indonesia. Yogyakarta: Program Studi S2 Linguistik Fakultas Ilmu Budaya UGM Yogyakarya bekerja sama dengan Pustaka Pelajar. 